\title{
Talking Trash: Ethics, Sustainability, And Organizational Trust
}

\author{
C. Kenneth Meyer, Ph.D, Drake University, USA \\ Sara Kurovski, Mayor of Pleasant Hill, Iowa, USA \\ Stephen E. Clapham, Ph.D., Drake University, USA
}

\begin{abstract}
In 1960 Americans generated 88.1 million tons (2.68 lbs./person/day) of municipal solid waste (MSW), by 2012 municipal solid waste increased to 250.9 million tons (4.38 lbs./person/day). The good news is that of the total MSW 5.6 million tons was recycled in 1960 and by 2012 the amount surged to 86.6 million tons. This real-world case (to protect privacy, names have been changed) chronicles the development of a strategic supply chain decision within a heavily regulated industry that is characterized by hybrid public/private organizations. It illustrates the importance of contract compliance and quality control assessment. In addition, it is heavily imbedded within the sustainability conversation. Finally, integral elements of the case are ethics and organizational trust, which, regardless of contract obligations, is essential in reciprocal relationships and community/customer support.
\end{abstract}

Keywords: Sustainability, Trustworthiness, Environmental Management, Recycling, Waste Management, Board Of Directors, Transparency, Accountability, Ethics, Organizational Trust

Suggested Courses: Case Studies in Management, Public Administration or Public Policy Analysis; Strategic Management; Environmental Management; Sustainability, and Business Ethics

\section{INTRODUCTION}

$\mathrm{t}$ is estimated that the world population in 2014 is over seven billion people. Each and every one uses
the earth's resources, albeit, some societies use far more than others. Nevertheless, humans use and
discard enormous amounts of the earth's treasures. In addition, we have created materials and chemicals that do not naturally exist, which has exacerbated the use and disposal problem. Historically, when there were far fewer individuals, natural resources were viewed as endless and indestructible, conservation was hardly a consideration. Rachel Carson's book, Silent Spring, published in 1962, has been attributed with launching the 'environmentalism movement.' In late 1969 Congress passed the National Environmental Policy Act (NEPA) and on April 22, 1970, some 20 million Americans from coast to coast participated in the first "Earth Day" rallies. That same year, on December 2, President Nixon, by executive order, created the Environmental Protection Agency (EPA). Nixon stated he had "become further convinced that the 1970s absolutely must be the years when America pays its debt to the past by reclaiming the purity of its air, its waters, and our living environment, it is literally now or never." The Resource Conservation and Recovery Act (RCRA) was passed in 1976. The RCRA amended the Solid Waste Disposal Act of 1965 and set national goals for protecting human health and the environment from the potential hazards of waste disposal.

Much has been accomplished since these and other regulations have been strengthened and created, in spite of a well-funded disinformation campaign where environmentalists have been ridiculed and the science has been disputed. Environmentalism has been subsumed into the broader concept of sustainability. Saving the earth for future generations is a significant part of sustainable awareness and actions/policy. But, positively affecting the human condition by eliminating hunger and disease, providing adequate health care, providing access to potable water and sanitary conditions, adequate housing, improving economic conditions, etc. is included within the more encompassing term - sustainability. 


\section{PART 1}

\section{Board Of Directors Receives Notification Of Lawsuit}

Anne Carlson was no stranger to boardroom meetings and knew from her many years of being a liaison to governing boards that the subject matter discussed around the table could range from the "inane" to core organizational values and business strategy. This time the board meeting was called on short notice and with urgency and highest priority.

As Anne sat back and watched, the board members "rifled" quickly through the mound of paperwork that had been laid in front of them. They raised their eyes and with "dart-like" glances, scanned each other's facial expressions as they collectively learned that they were all joined as parties (defendants) to a lawsuit that had been filed against them. Their disbelief in what they had just read turned to questions that they directed toward Charles Bremer, Executive Director of Jacksonville Waste Control Agency (JWCA). They asked how "...they could as board members be sued? Why Bremer and his staff had permitted the aggrieved situation to take place? Was due diligence done before the contract in dispute had been signed?" Anne thought these were important enough questions, but why were they being asked for the first time now.

The board and the executive director sat quietly and their body language revealed a state of personal distress, anxiety and shock! The quietude was broken when James Murphy motioned for the board to go into closed session and it was quickly seconded by a number of his colleagues. The board was comprised of one elected official from each of the ten member communities or jurisdictions served by JWCA and headed by the executive director.

Anne, who was not on the board, served the board as a principal staff liaison person, gathered her own paperwork and with the other employees and guests who were in attendance, walked out of the boardroom. Not one known for idle "chit-chat," she returned to her office, closed the door quickly and pondered how this problem could have happened. She did her best to reclaim her memory of the process that was put into place when the idea for a joint operation with a private company was proposed, then executed and now in litigation. And, now the historical picture was being played out in her mind's eye as she attempted to summon up the past-a recollection that was complete in substance but lacked a definite timeline.

\section{A Meeting Of The Senior Management Of JWCA}

It was a typical Friday morning meeting of the senior management of the JWCA, she recalled. Weekly, the senior managers met to be briefed and updated on issues, projects, and opportunities associated with JWCA operations and activities. Like so many previous weekly meetings, the discussion turned to the "construction and demolition" debris problem. In brief, JWCA owned and operated the regional solid waste landfill facility, as well as several recycling and other disposal facilities. JWCA was not just an "also ran" landfill operation; it was known nationally for its ethics, compliance with environmental standards, and the sustainable programs it had developed, supported, and furthered nationally. The landfill received well over a million tons of municipal solid waste (MSW) each year, and the landfill tipping (dumping) fee was its basic source of revenue to cover costs; JWCA did not receive, like so many other landfill operations, either tax supported monies or per capita fees. As usual, the board was concerned with the magnitude of construction and demolition waste that was going directly into their site and this was troubling to them since they understood how it could be severely reduced by using available technology and alternative landfill cover processes similar to those being effectively employed at other sites around the country.

Jack Wells, the director of operations, stated "...the total amount of construction and demolition (C\&D) debris they disposed of had increased by five percent each year over the past decade - a combined increase of fifty percent." The senior management team once more nodded in agreement that this was a major problem and this memory lived in Anne's mind as if the event had just occurred.

As Anne's memory came to light, she recalled how JWCA had been "tip-toeing" around the debris issue and had not determined if the organization would remain static or take a bold, new position on C\&D. She understood then that since JWCA was a quasi-governmental organization, that their private sector, for profit, 
counterparts would be upset if they knew the full implication of what JWCA was planning to do-a concern often publicly voiced to the managerial staff by the executive director. Anne always sat back and listened intently to the board's discussion and she recalled playing a simple game of chess in her head as she saw "moves and countermoves" and different strategies employed as different interests reacted in predictable ways to JWCA's proposed inauguration of a $C \& D$ facility. She recalled how she interjected herself into the discussion at one point and said "I believe we should put out a Request for Proposal (RFP) - one on which JWCA could also submit a bid. If some private sector company subjects a better bid, then the case is closed and the problem is solved."

Anne retained remembrances of Bremer responding, “...there is only one problem with your suggestion Anne. We know that if we run our own C\&D operation, it will be done ethically, effectively, and in a fiscally transparent and responsible manner." As Anne thought back in time, she fully understood the correctness of the executive director's statement.

As Anne picked through the memories stored in her mind, she called-up the idea that during the subsequent few weeks that followed the board's meeting in which the C\&D proposal had been aired, that it was an uneventful time for JWCA as management began developing plans and strategies that would move them forward on the different options they might eventually propose. To her satisfaction, then as now, Anne thought the planning for the proposed new facility had all of the key organizational participants involved: the Chief Financial Officer (CFO), the Director of Operations (DOO), the Compliance Manger (CM), and the Manager of Public and Community Relations (MPCA). The time would come when the DOO would present the C\&D facility proposal.

\section{“Calling Back" To Mind, Reflections, And Retrospection}

During her brief reflection, there were many thoughts, facts, issues, and recollections that had surged through her mind. But she was pleased with herself that she had recalled with clarity the situation in which the idea to use ground-up construction and demolition material, mixed with soil as an alternative daily cover for their landfill, was initially proposed by the DOO. Those at the meeting certainly knew, she thought, that landfills had to cover their garbage daily as mandated by federal and state regulations, in order to reduce odors, vectors, and other environmental problems and that soil cover cost was a major operational expense. She knew about other landfills that were already using alternative coverage as a soil substitute and saving large sums of money, while increasing the recycling market for construction and demolition operators. Indeed, she recalled once senior manager saying "...it would be a win-win for JWCA and the private sector. JWCA would use the ground-up construction and demolition waste and the private company that operated the $\mathrm{C} \& \mathrm{D}$ facility would have an end user (market) for one of their products."

In retrospection, she was amazed as to how her memory had been able to summon up the chronology of events that surrounded the development of the land cover concept. She rebuilt in her mind the fact that JWAC had hired consultants to develop the specifics of the program and to answer these questions: How many tons of material would JWAC be able to accept per day/week/month or year to use as cover? What, if any, environmental consequences would be associated with using pulverized construction and demolition refuse for landfill cover? What would be the composition of the ground up material used in the landfill? Would the Department of Health and Environmental Services (DHES) permit them to use the material as alternative daily cover? Would core and other samples need to be taken of the materials supplied and what would need to be sampled-landfill or tipped tonnage? And, could JWAC take the material for free from the private recycling company? The consultants worked diligently and sought outside resources in their attempt to answer all of the questions.

\section{Designing Specifications For Recycling And Solid Waste Disposal For JWCA}

After a few months of researching and examining the issue, a set of specifications were designed for JWCA to use once a private construction and demolition recycler came on board. By now, JWAC's plans had become common knowledge to the recycling and refuse community; that JWCA was looking into the new coverage material and that a specific vendor was planning to open a construction and demolition facility within sixty days or so. 
As Anne recalled it was nearly a year after the alternative landfill idea had been discussed, that Travis Recycling (TR), a private facility, had been built and began producing the cover material for JWAC. A contract had been signed between JWCA and Travis Recycling and the board of directors at JWCA designated the facility to operate within their service area. The JWCA board had the power, she recalled, much like a permitting authority, to designate which recycling vendors could operate within the same service areas as the landfill. With a facility designated, it became the responsibility of JWCA and its board of directors to ensure that Travis Recycling was environmentally and fiscally responsible. As she looked back over the events that had transpired, everyone, it seemed to her, was excited about the new public-private partnership - an excitement that quickly ended when the meeting of the senior managers was called to deal with the strong, obnoxious odor that emanated from the landfill.

\section{Was Travis Recycling In Compliance With The Law And The Need For A Compliance Audit?}

She probed her memory once more and recalled that less than a year had passed since JWCA started accepting the material from Travis Recycling and the field sanitarians and some of the larger customers started complaining about the strong odors - that a toxic smelling stench was more foul than the typical landfill smells. Simultaneously, the company that extracted methane from the landfill and turned it into energy--Methane2Energy (M2E) was experiencing higher levels than normal of hydrogen sulfide in the collected gas and they were upset and worried because hydrogen sulfide could potentially destroy the multi-million dollar facility that had been installed to collect the methane. Management at JWCA was also worried about this new level of toxicity, because of the associated health hazard it posed for their employees. Senior management began to troubleshoot the problem and it was not until the compliance manager presented some sampling information that the light bulbs went off in everyone's heads. The sample results revealed that there were high levels of gypsum in the ground up construction and demolition material, and when gypsum gets wet and decomposes it releases a high level of hydrogen sulfide.

The writing was on the wall. Travis Recycling was not in compliance with either the contract guidelines or with the standards set forth by the Department of Environmental Protection (DEP). Accordingly, the DEP ordered that samples be taken from every load of material that was sent to the JWCA facility for use as cover, and halted the use of all alternative cover material that did not meet the contracted specifications. Rejected cover was taken to the landfill and a standard tipping fee for construction and demolition waste was billed to Travis Recycling.

Anne was pleased with her ability to reconstruct in her mind the sequence of events that led up to the lawsuit. She knew the serenity of her office and the immediacy of the problem certainly helped her rebuild the sequence of events she depended upon now. She was ready to answer questions that the board might have about the chronology of actions taken by the staff if she was called upon to revisit them in a staff meeting.

As the closed session ended, senior management directed the compliance manager to perform an audit for JWCA of the Travis Recycling facility. The audit revealed that they were grinding all of the material they received and were not separating the various recycled materials. The compliance manager found that tons of ground up material had accumulated on the recycling site and that Travis Recycling had become a laughing joke to neighbors who felt that a new mountain range in Jacksonville was being built. Accordingly, Travis Recycling was informed that they would be billed for all materials that did not measure up to the contractual specifications and demanded that they follow their agreed upon obligations in the future. As the compliance monitoring was continued, JWCA realized that none of the alternative cover materials arriving at the landfill met the engineering specifications, and accordingly, Travis was billed for all of the dumped tonnage. In strong reaction, Travis Recycling filed a lawsuit against JWCA.

\section{Was Travis Recycling A “Green Leader?” Or, Was The Complete Story On JWCA Still To Be Told?}

Anne sat back at her desk and looked at the news clipping she had collected about Travis Recycling. The local media had referred to Travis Recycling, as "...the new leader in recycling initiatives," and as "...the green leaders in Jacksonville." They had been hailed as an easy, one stop shop for construction and demolition recycling. Anne smiled in disagreement because she had additional facts. She knew that all of the debris that had come to JWCA from Travis Recycling, except for metals, had not measured up to the agreed upon standards. As she paged through the documents she had clipped, she read another newspaper article in which the owner of TR discussed how 
they were prepared to assist all regional contractors in meeting the Leadership in Energy and Environmental Design (LEED) goals for recycling construction and demolition waste. In Ann's mind, TR was nothing more than a sham operation - they had billed themselves as a recycling company but they were merely land filling all materials received.

Several days after the board of directors meeting had ended, the executive director came into Ann's office. Looking up at him she said, "I want to go public with the information about what has been going on here and explain what Travis Recycling has done." In response, the executive director stated "We are a party to a lawsuit now and our legal counsel has advised us not to say a word and wait for the legal system to run its course. So we must remain silent on this issue and cannot say anything negative about Travis Recycling."

Ann reclined in her chair and contemplated the long road that lie ahead and wondered how in the world JWCA got into this situation in the first place.

\section{Instruction And Questions, Part 1:}

1. What would you do if you were in Ann's situation? Please map-out a strategy that you would utilize if asked by the Executive Director for your recommendation. Please be specific.

2. If you were Charles Bremer, the Executive Director, what would you do to maintain JWCA's organizational image through the lawsuit?

3. If you were Executive Director Bremer, how would you work with your board to keep them informed and up-to-date on the lawsuit? After all, they could place blame on Bremer for allowing this to happen.

4. Since JWCA designates which recycling facilities can operate in their service area, do you think the board should immediately de-designate Taylor Recycling? If so, why? If not, why not? Please elaborate.

5. Identify and list at least four key differences between the private and governmental sectors and indicate how these attributes affect their contractual operations. Please be specific. Do you think the differences you have identified would impact future contractual relationships, and if so, in what ways? Please discuss.

\section{PART 2}

STOP before reading this section of the case. Once you have addressed the previous five items in the Questions and Instructions portion above, proceed to Part 2 of this two-part case study.

Anne Carlson had an uneasy feeling in her stomach as she strained with the tug-of-war between what was legally permitted by law and what was morally or ethically right. She knew that JWCA could be in its throws of survival, especially if the case went to trial. As a professional administrator, she wanted to do what was right!

\section{Issues Of Trust And Ethics Are Considered}

William Ochi argues "...people must either be able to trust each other or to closely monitor each other if they are to engage in cooperative enterprises" (1989). "A significant residual of trust violation is the increase in the cost of monitoring. In a more trusting environment, finite resources can be used for activities that generate returns rather than for monitoring activities that have no return" (Clapham, Meyer, Caldwell, Proctor, 2013). Organizational leaders are under enormous pressure from stakeholders to achieve success (however that is defined). In today's global environment with varying industry regulations, tax structures, governance structures, labor rates, economic conditions, etc., growing enterprise value is more difficult than ever. This pressure and/or personal greed have led some leaders to make unethical and even fraudulent decisions.

Trust and ethics are intertwined. Caldwell and Clapham (2003) stated "...interpersonal trustworthiness is individually determined and based upon each individual's ethical perceptions regarding the duties to which he or she is owed by the person whose objective behaviors are being observed." While the 2013 National Business Ethics Survey found that observed overall misconduct declined substantially from previous years, the disturbing trend is that upper-level leaders are more likely to break the rules than those at lower-levels, "...the very people that are supposed to act as role models or enforce discipline are often guilty of bad behavior." There are three types of 
ethical leaders: moral - dedicated to the highest standards of ethical behavior; immoral - have no regard for ethical standards; and amoral - follow letter of laws and ignore the intent when it is advantageous, in other words, "how much can we get by with." Mayer, Davis, and Schoorman have posited that individuals' perception of trustworthiness in an individual or organization is dependent upon three factors: the ability to accomplish a task; integrity - will the agreement as promised; and benevolence - a strong desire to serve the needs of another. If there is a negative perception of ability by either party it is highly unlikely that a contract will be pursued, if there is a weak perception of either of the other elements (or both) a contract may be entered and the degree of contract specificity will depend upon the perceived risk.

\section{Instruction And Questions, Part 2:}

6. From an ethical perspective discuss Anne's options of remaining silent or going public, describe how each party would most likely be effected by each option.

7. Describe the ethical types for the leaders of each organization.

8. Describe what each party had to risk by entering into the contract.

9. What policies would you recommend that JWCA create in light of this event?

\section{AUTHORS' INFORMATION}

C. Kenneth Meyer (kenneth.meyer@drake.edu) is Thomas F. Sheehan Distinguished Professor of Public Administration, Drake University. He previously held teaching positions at Winona State University, State University of New York, University of South Dakota and the University of Oklahoma, Norman, Oklahoma. He has nearly 300 published case studies that appear in numerous venues. His latest books are entitled: Managing People as Assets; Human Relations in Action; Managing America's Organizations; and Managing Public Service Organization; Conducting the People's Business; and Organizational Change. His newest book is entitled Nonprofit Management and Leadership Case Studies (2014).

Stephen E. Clapham (steve.clapham@drake.edu) is a professor of management in the Drake college of Business and Public Administration. He earned his Ph.D. from Indiana University. He has published research in the areas of trust, ethics, strategic planning, organizational voice, and impression management.

Sara Kurovski is the Mayor of Pleasant Hill, Iowa and also the Manager of Sustainability for Kum \& Go. She earned her Master's in Public Administration from Drake University and her undergraduate degree in Communication Studies from Truman State University. She spends most of her 'free' time serving on different boards and commissions in Polk County, Iowa.

\section{REFERENCES}

1. Caldwell, C. and Clapham, S.E. (2003). Organizational Trustworthiness: An International Perspective, Journal of Business Ethics, 47, 349-364.

2. Clapham, S.E., Meyer, C.K., Caldwell, C., and Proctor Jr., G.B. (2013). Trustworthiness, Justice and the Mediating Lens, Journal of Business and Behavioral Sciences, 26,1, 55-74.

3. Construction and Demolition Waste Landfills: http://www.epa.gov/osw/hazard/generation/sqg/const/cdrpt.pdf

4. Garvey, James (2008). The Ethics of Climate Change, Continuum International Publishing Group, New York, New York.

5. ISM Principles of Sustainability and Social Responsibility: With a Guide to Adoption and Implementation (2008). Institute for Supply Management, Inc., Tempe Arizona.

6. Managing Nonhazardous Solid Waste. http://www.epa.gov/epawaste/inforesources/pubs/orientat/rom2.pdf

7. Municipal Solid Waste Generation, Recycling, and Disposal in the United States: Facts and Figures for 2012: http://www.epa.gov/osw/nonhaz/municipal/pubs/2012_msw_fs.pdf

8. National Business Ethics Survey of the U.S. Workforce (2014). Ethics Resource Center, Arlington, VA.

9. Ouchi, W. (1989). A Conceptual Framework for the Design of Organization Control Mechanisms, Management Science, 25(9), 833-848.

10. Schoorman, F.D , Meyer, R.C., and Davis, J.H., (2007). An Integrative Model of Organizational Trust: Past, Present, and Future, Academy of Management Journal, 32(2), 344-354. 


\section{APPENDIX}

Talking Trash: Ethics, Sustainability and Organizational Trust, Name:

\section{Case Log and Administrative Journal Entry}

This case analysis and learning assessment may be submitted for either instructor or peer assessment

\section{Case Analysis:}

Major case concepts and theories identified:

What is the relevance of the concepts, theories, ideas and techniques presented in the case to that of public or private management?

Facts - what do we know for sure about the case? Please list.

Who is involved in the case (people, departments, agencies, units, etc.)? Were the problems of an "intra/interagency" nature? Be specific.

Are there any rules, laws, regulations or standard operating procedures identified in the case study that might limit decision-making? If so, what are they?

Are there any clues presented in the case as to the major actor's interests, needs, motivations and personalities? If so, please list them.

\section{Learning Assessment:}

What do the administrative theories presented in this case mean to you as an administrator or manager?

How can this learning be put to use outside the classroom? Are there any problems you envision during the implementation phase? 
Several possible courses of action were identified during the class discussion. Which action was considered to be most practical by the group? Which was deemed most feasible? Based on your personal experience, did the group reach a conclusion that was desirable, feasible, and practical? Please explain why or why not.

Did the group reach a decision that would solve the problem on a short-term or long-term basis? Please explain.

What could you have done to receive more learning value from this case?

\section{Case Supplement for Problem Solving Approach:}

Case study analysis takes into consideration the different substantive and experiential backgrounds of a diverse set of learners as they address the central questions and instructions associated with the incident. As such, the principle of equifinality is encouraged in the discussion and decision making components of the analysis. Succinctly, there is no one best way to answer these questions - - there are many different approaches and each decision has its own strengths and limitations. The questions and instructions presented in the case are not intended to be exhaustive, but rather are designed to start a fermentation process leading to other questions, issues and ideas. Historically, case study methodology focused on "...the answer is, the answer is," but answers change as additional information is discovered. Now, it is important, if not more important, to ask, as Peter Drucker advised years ago: "What is the question."

John Dewey in his description of the problem-solving method distinguished five steps or phases. These are: (1) the recognition of a problem, (2) the definition and clarification of the problem, (3) the rise of possible solutions, (4) the development by reasoning of the implications of the solutions, and (5) further observation and experimentation leading to acceptance or rejection of the solutions. These phases comprise an oversimplification of what Dewey called "reflective thinking" about a problem or situation.

One of the great strengths of this problem-solving method is that administrators learn to avoid pre-judgment, bias, and prejudice and come to grips objectively with the issues at hand. The case embodies complex human situations and interactions with other people who behave like people -- that is they sometimes behave rationally and at other times irrationally, they are subject to persuasion by emotion and/or logic but are not easily manipulated like pieces on a chessboard. In diagnosing a problem and seeking a remedy, one's personal motivations must be examined. Sometimes administrators take a short cut and at other times they vacillate and delay rather than putting a firm hand on the difficulties they encounter. At other times, they put their own personal interests above the public good and the employees and organizations they serve. 